\title{
Time to cash in on positive interactions for coral restoration
}

\author{
Elizabeth C Shaver ${ }^{\text {Corresp.. }}{ }^{1}$, Brian R Silliman ${ }^{1}$ \\ ${ }^{1}$ Division of Marine Science and Conservation, Nicholas School of the Environment, Duke University, Beaufort, North Carolina, United States \\ Corresponding Author: Elizabeth C Shaver \\ Email address: ecs39@duke.edu
}

Coral reefs are among the most biodiverse and productive ecosystems on Earth, and provide critical ecosystem services such as protein provisioning, coastal protection, and tourism revenue. Despite these benefits, coral reefs have been declining precipitously across the globe due to human impacts and climate change. Recent efforts to combat these declines are increasingly turning to restoration to help reseed corals and speed-up recovery processes. Coastal restoration theory and practice has historically favored transplanting designs that reduce potentially harmful negative species interactions, such as competition between transplants. However, recent research in salt marsh ecosystems has shown that shifting this theory to strategically incorporate positive interactions significantly enhances restoration yield with little additional cost or investment. Although some coral restoration efforts plant corals in protected areas in order to benefit from the facilitative effects of herbivores that reduce competitive macroalgae, little systematic effort has been made in coral restoration to identify the entire suite of positive interactions that could promote population enhancement efforts. Here, we highlight key positive species interactions that managers and restoration practitioners should utilize to facilitate the restoration of corals, including i) trophic facilitation, ii) mutualisms, iii) long-distance facilitation, iv) positive density-dependence, v) positive legacy effects, and vi) synergisms between biodiversity and ecosystem function. As live coral cover continues to decline and resources are limited to restore coral populations, innovative solutions that increase efficiency of restoration efforts will be critical to conserving and maintaining healthy coral reef ecosystems and the human communities that rely on them. 
1 Time to cash in on positive interactions for coral restoration

2

3 Elizabeth C. Shaver* and Brian R. Silliman

4

5

6 Division of Marine Science and Conservation, Nicholas School of the Environment, Duke

7 University, Beaufort, NC, USA

8

9

$10 *$ Corresponding author

11 Elizabeth Shaver

12 elizabeth.schrack@duke.edu

13

14

15

16

17

18

19

20

21

22

23 


\section{Abstract}

25 Coral reefs are among the most biodiverse and productive ecosystems on Earth, and provide

26 critical ecosystem services such as protein provisioning, coastal protection, and tourism revenue.

27 Despite these benefits, coral reefs have been declining precipitously across the globe due to

28 human impacts and climate change. Recent efforts to combat these declines are increasingly

29 turning to restoration to help reseed corals and speed-up recovery processes. Coastal restoration

30 theory and practice has historically favored transplanting designs that reduce potentially harmful

31 negative species interactions, such as competition between transplants. However, recent research

32 in salt marsh ecosystems has shown that shifting this theory to strategically incorporate positive

33 interactions significantly enhances restoration yield with little additional cost or investment.

34 Although some coral restoration efforts plant corals in protected areas in order to benefit from

35 the facilitative effects of herbivores that reduce competitive macroalgae, little systematic effort

36 has been made in coral restoration to identify the entire suite of positive interactions that could

37 promote population enhancement efforts. Here, we highlight key positive species interactions

38 that managers and restoration practitioners should utilize to facilitate the restoration of corals,

39 including i) trophic facilitation, ii) mutualisms, iii) long-distance facilitation, iv) positive density-

40 dependence, v) positive legacy effects, and vi) synergisms between biodiversity and ecosystem

41 function. As live coral cover continues to decline and resources are limited to restore coral

42 populations, innovative solutions that increase efficiency of restoration efforts will be critical to

43 conserving and maintaining healthy coral reef ecosystems and the human communities that rely

44 on them.

45

46 


\section{Introduction}

Coral reefs are one of the most biodiverse and productive ecosystems on Earth, and

49 provide critical services to at least 500 million people throughout the world (Wilkinson 2004). In

50 addition to supporting healthy and thriving human communities through food provisioning,

51 coastal protection, and tourism revenue, coral reefs are essential ecosystems within the landscape

52 of coastlines, facilitating seagrass, mangrove, and terrestrial habitats (Dorenbosch et al. 2005,

53 Mumby et al. 2004). Despite the many benefits to both natural and human communities, coral

54 reefs around the world are rapidly degrading due to a combination of human activities and

55 climate change. In response to these losses, conservation efforts are increasingly turning to

56 restoration as a strategy to promote coral reef recovery by transplanting colonies that will

57 hopefully grow, reproduce, and reseed reefs (Johnson et al. 2011, Young et al. 2012). Although

58 active coral transplantation efforts are increasing across the globe (Lirman and Schopmeyer

59 2016), restoration remains costly (median, $\$ 162,455$ US per ha) and most projects are done on

60 small temporal (1 yr) and spatial smalls (<1 ha) (Bayraktarov et al. 2016). Transplant

61 survivorship, however, has been high relative to other habitats (64.5\% survival) (Bayraktarov et

62 al. 2016); thus, coral restoration shows promise but requires further innovative approaches that

63 improve restoration efficiency. Increased yield for each conservation dollar spent will be critical

64 if we are to reach restoration scales needed to rehabilitate large enough coral populations that

65 restore coral reef processes and services at the ecosystem level.

66 For many decades, the paradigm in coastal conservation has been to minimize negative

67 interactions (e.g., competition) between transplant neighbors (Silliman et al. 2015). This

68 paradigm was transferred directly from forestry science, which developed in the late 1940s

69 (Halpern et al. 2007). However, positive interactions are common in marine systems and often 
70 play pivotal roles in ecosystem development and recovery (Bruno and Bertness 2001). For

71 instance, a mutualism between salt marsh grasses and ribbed mussels is key to salt marsh

72 resilience and recovery after severe drought events, as mussel mounds increase nutrients and

73 water retention that reduces marsh grass mortality during drought (Angelini et al. 2016). In kelp

74 forests, predator populations promote ecosystem resistance and recovery by indirectly facilitating

75 kelp populations through a trophic cascade (Estes and Palmisano 1974). Positive species

76 interactions in coral reef ecosystems could likewise be identified and used to assist in the active

77 recovery of coral populations and habitats.

78 With increased consideration of facilitation in ecological theory (Bruno et al. 2003),

79 recent papers have also recently made the case for systematically including positive interactions

80 in aquatic and coastal restoration (Halpern et al. 2007, Gedan and Silliman 2009). Unfortunately,

81 a decade later, a survey of coastal wetland conservation agencies found that reducing negative

82 interactions was still the predominant focus in wetland restoration designs (Silliman et al. 2015).

83 Subsequent experimental studies showed that altering restoration practices to instead harness

84 positive species interactions increased transplant survivorship by $\sim 100 \%$ and biomass by $\sim 200 \%$

85 with no additional cost (Silliman et al. 2015). Efforts in coral reef restoration, however, have not

86 been made to systematically use facilitation in restoration designs, even though numerous

87 positive interactions have been identified in ecological studies (e.g., herbivores that facilitate

88 corals by suppressing algae, crustose coralline algae that promotes coral settlement). Indeed, a

89 Web of Science search for coral restoration studies from 1980-2016 (generating 104 studies; see

90 Fig. 1 for search terms) shows very few studies (10 studies, 9.6\%) have examined positive

91 interactions in a restoration context, with most of these papers focusing on herbivore-algae

92 interactions (6 studies, Fig. 1). Below, we highlight positive interactions that naturally occur on 
93 coral reefs around the world that may be available to use to enhance coral restoration success and

94 thus increase the efficiency and scale of these efforts.

95

96 Trophic facilitation

97 Trophic facilitation occurs when one species is positively impacted through the feeding

98 activities of another. One example includes trophic cascades where predators, by suppressing

99 densities of primary consumers, can increase densities of basal prey species such as plants (e.g.,

100 effects of wolves on shrub communities in the Great Lakes: Callan et al. 2013; effects of otters

101 on kelp forests in the Pacific: Estes and Palmisano 1974). Another common example occurs

102 when consumers facilitate species that are competitively inferior. For instance, ungulates in

103 North America (Beschta and Ripple 2009) and elephants in Africa (Sinclair et al. 2010) can

104 facilitate grassland persistence by preferentially feeding on saplings, thereby suppressing the

105 growth of competitively dominant trees.

106 In coral reefs, the facilitation of corals by herbivores (via suppressing the overgrowth of

107 macroalgae) has been studied for decades. Results of comparative and experimental studies have

108 shown that herbivorous fish and urchins are critical for the success of corals, and this positive

109 interaction is general across almost all regions where corals occur (Ogden and Lobel 1978, Hay

110 1984, Mumby et al. 2006, Burkepile and Hay 2008). Because of this research, coral conservation

111 programs often focus on harnessing the positive impacts of herbivores on corals (e.g., NOAA

112 Acropora Recovery Plan: NMFS 2015), and many restoration manuals likewise recommend

113 transplanting corals in areas with high herbivore densities, such as in marine protected areas

114 (MPAs; Caribbean Acropora Restoration Guide: Johnson et al. 2011) (Fig. 2). Despite the

115 incorporation of these ecological findings into restoration, no studies to date have experimentally 
116 evaluated the effects of coral restoration success in areas with high vs. low herbivore abundance.

117 This work is ultimately important as many reef herbivores can negatively affect corals or reef

118 systems by acting as corallivores or bioeroders of reef framework. Recent research suggests that

119 grazing may be more detrimental on degraded reefs with few living corals and reduced reef

120 accretion rates (Rotjan and Lewis 2008, Mumby 2009, Kuffner and Toth 2016). Therefore,

121 taking advantage of ecological interactions that facilitate corals for restoration must also include

122 rigorous evaluation of their effects and can include assessing threshold effects or evaluating how

123 different species vary in their functional roles (as suggested by Rotjan and Lewis 2008). In

124 addition to macroalgae, future restoration designs may also benefit from extending this research

125 to examine how trophic interactions also influence other benthic coral competitors such as

126 sponges, fire corals, and mat-forming zoanthids.

127 In contrast to the indirect effects of herbivores on corals, trophic cascades and direct

128 predation on corals have been considered within the context of restoration and conservation to a

129 far lesser extent. There is experimental and observational evidence, however, to suggest that

130 trophic cascades and food web linkages can positively affect coral populations. For instance,

131 experimental removals of pufferfish in the Caribbean showed that these fish can facilitate soft

132 corals by reducing populations of corallivorous flamingo tongue snails (Burkepile and Hay

133 2007). Similarly, the breakdown of trophic cascades due to overfishing has also been suggested

134 to lead to population outbreaks of corallivores such as nudibranchs in Hawaii (Gochfield and

135 Aeby 1997), Drupella snails in the Western Indian Ocean (McClanahan 1997), and crown-of-

136 thorns starfish in Fiji (Dulvy et al. 2004). No research has yet been attempted to evaluate the

137 positive effects of trophic cascades on coral restoration success, even though the potential to

138 enhance restoration efficiency is high given that corallivores are common sources of mortality 
139 for new coral transplants (Schopmeyer \& Lirman 2015, Lirman and Schopmeyer 2016).

140 Additionally, much time and manpower are currently being invested in the Caribbean to

141 manually remove corallivores from transplants (Williams et al. 2014, NMFS 2015). Like

142 herbivores, one of the best places to examine these effects may be within effectively managed

143 MPAs where predators of corallivores should theoretically be higher (Fig. 2).

144 Beyond tri-trophic facilitation corals through predator control of corallivores, a more

145 general discussion has emerged over whether top predators can create interactions that trickle

146 down to positively affect coral populations. The evidence so far has been equivocal, as recent

147 observational research correlating top predators with coral or algal-dominated systems have

148 found varying results (Sandin et al. 2008, Ruppert et al 2013) potentially caused by the fact that

149 top predators often feed on multiple trophic levels (Valentine and Heck 2005). Despite this, more

150 direct trophic linkages may be found that can be used specifically for restoration when corals are

151 most vulnerable (i.e., when they are first transplanted and small), for instance protecting a

152 predator that strongly controls populations of a particular corallivore population. The ambiguity

153 and paucity of experiments in this research avenue, and therefore its use in informing coral

154 restoration practices, highlights the great need for more research on how complex food web 155 interactions can facilitate coral populations.

157 Mutualisms

158 Mutualistic interactions, or reciprocal positive interactions between species, are

159 fundamental to the success and persistence of foundation species in many marine and terrestrial

160 ecosystems. For example, mutualisms between plants and mycorrhizal fungi underlie forests

161 (Dighton and Mason 1985) and salt marshes (Daleo et al. 2007) by facilitating plant colonization 
162 in otherwise stressful environments. Other reciprocal positive interactions facilitate the

163 persistence of foundation species by protecting them from natural enemies. An example of this is

164 the symbiosis between ants and Acacia trees, where ants protect trees from antagonistic species

165 (stem boring beetles: Palmer et al. 2008) and pathogens (González-Teuber et al. 2014) in

166 exchange for refuge and habitat. Similarly, the formation of coral reefs throughout the tropics

167 would not occur without a mutualism between corals and photosynthetic algae (Symbiodinium),

168 which provide substantial nutrition to corals and enhance skeletal deposition (Goreau and Goreau

169 1959). Because of the high biodiversity on coral reefs, there are likely many reciprocal positive

170 interactions that promote coral success and that be identified for use in restoration designs.

171 The relationship between corals and crustose coralline algae (CCA) is one of the most

172 well-known reciprocal positive interactions that can encourage healthy coral reef functioning.

173 While coral reefs provide habitat, CCA is critical for cementing and stabilizing reef structure and

174 facilitating settlement of coral larvae (Heyward and Negri 1999). Reef-dwelling sponges are also

175 important for substrate stabilization as well as food web nutrient cycling through the conversion

176 of detritus into food resources for reef consumers (De Goeij et al. 2013). Other mutualisms can

177 increase restoration efficiency by reducing the harmful effects of natural enemies on corals. In

178 French Polynesia, for example, amphipods that live in corals of the genus Montipora protect

179 corals from predatory seastars (Bergsma \& Martinez 2011, Bergsma 2012). Similarly,

180 mutualistic crabs in the Pacific increase the survivorship and growth of branching corals by

181 reducing sedimentation (Glynn 1976), predation by crown-of-thorns seastars (Pratchett and

182 Vytopil 2000, Pratchett 2001), and vermetid snail effects (Stier et al. 2010). Many fish species

183 that use coral reefs for habitat can also promote coral growth by enhancing the transfer of

184 nutrients in areas where macroalgae are trophically controlled (Burkepile et al. 2013). 
186 date have examined or experimented with incorporating species-specific mutualisms into

187 restoration. One recent study that seeded a reef with sponges prior to transplanting corals found

188 significant increases in rubble consolidation that in turn enhanced coral survivorship in that

189 environment (Biggs 2013). Similarly, an experiment that explicitly transplanted corals in areas

190 with high and low abundances of grunts showed that fish significantly increased coral

191 survivorship and growth through nutrient transfer (Shantz et al. 2015). These studies reveal that

192 reciprocal positive relationships can be used in innovative and strategic ways in a restoration

193 context. Thus, future restoration designs across regions should seek to identify local mutualisms

194 that can be harnessed to increase success naturally without additional manpower.

195

196 Long-distance facilitation

197 Positive interactions can also occur between species that are not in contact but separated 198 by distances of tens or thousands of meters (van de Koppel et al. 2015). Long-distance, positive 199 impacts can be generated by the amelioration of physical and/or biological stress. For instance, in 200 coastal habitats the structure of intertidal oyster reefs reduces wave energy and erosion allowing 201 mud flats to accrete behind reefs, which then provide a suitable environment for the development 202 of relatively wave-intolerant salt marsh grasses (Meyer, Townsend, and Thayer 1997). Long203 distance facilitation can also affect the spatial organization of ecosystems, such as bands of 204 mussel beds that form across large mud flats due to the interaction between local facilitation of 205 mussels but resource competition over larger areas (van de Koppel et al. 2015). As coral reefs are 206 often biologically and physically linked to adjacent tropical habitats, we examine potential long207 distance facilitations that may be useful for coral restoration. 
Decades of research has shown that the health, productivity, and biodiversity of coral

209 reefs is directly related to their proximity to tropical seagrass meadows and mangrove forests.

210 For example, both habitats facilitate corals by reducing stressors such as sedimentation or

211 nutrient pollution from coastal development and runoff that may smother corals or enhance algal

212 overgrowth (Christianen et al. 2013, Storlazzi et al. 2011). Seagrass meadows are also important

213 regulators of water quality, with recent surveys finding 2-fold less coral disease on reefs near

214 seagrasses (Lamb et al. 2017). Coral productivity may be enhanced by naturally-derived

215 nutrients from seagrasses or mangroves through detritus or the excrement of animals that forage

216 in those habitats but live on coral reefs (e.g., grunts: Shantz et al. 2015) (Fig. 2). In addition to

217 trophic linkages, seagrasses and mangroves can enhance the biomass and diversity of many reef-

218 associated species by acting as nursery habitat during critical early life stages (Nagelkerken \&

219 van der Velde 2002) (Fig. 3). Rainbow parrotfish, for example, are important large herbivores in

220 the Caribbean that are significantly higher on coral reefs next to healthy mangrove habitats

221 (Mumby et al. 2004), and in general the biomass of herbivorous fish is significantly reduced on

222 reefs without nearby seagrass and mangrove habitats (Dorenbosch et al. 2005, 2007).

223 Major barriers to the long-term survivorship of restored corals include disease and high

224 levels of macroalgae that block coral recruitment (NMFS 2015). However, planting corals

225 specifically near healthy mangrove and seagrass habitats could facilitate increased transplant

226 growth (e.g., increased nutrient transfer) and survivorship (e.g., reduced disease and macroalgae

227 due to herbivore biomass and diversity) (Fig. 3). Within reefs, corals could also benefit from

228 being planted near larger, established corals due to wave protection and/or spillover of facilitated

229 herbivores (i.e., urchins like Diadema) that live within the interstitial matrices of larger corals

230 (Fig. 3). Despite the great potential for long distance positive interactions to enhance coral 
231 restoration, little consideration has been to scientifically evaluate the effects of restoring corals

232 with and without adjacent and healthy mangroves or seagrasses, or near large corals within reefs.

233 These efforts could be further enhanced with more 'ridge to reef' management or protection

234 (e.g., MPAs) that encompass all coastal habitats from land out to coral reefs.

\section{Positive density dependence}

Positive density dependence is another mechanism that can enhance population recovery.

238 The role of intraspecific density on a population's growth and success has been examined in a

239 great number of organisms, including insects (e.g., Stiling 1987), plants (e.g., Harms et al. 2000),

240 and marine invertebrates (e.g., Levitan 1991), and can have both negative and positive effects.

241 Positive density dependence, or density-dependent facilitation, occurs when the success of

242 conspecifics increases at higher densities (i.e., the Allee effect: Allee 1931). For example, salt

243 marsh grasses and mangrove trees have higher survivorship and increased rates of recovery in

244 groups vs. in isolation because group benefits emerge from synergistic soil oxygenation and

245 structural protection from wave stress (Gedan and Silliman 2009, Silliman et al. 2015). Animal

246 aggregations, such as mussels and schooling fish, have increased success with higher densities

247 due to reduced predation pressure on individuals (Gascoigne and Lipcius 2004). Recent

248 ecological theory suggests that positive density dependent effects should be more prevalent

249 under stressful physical conditions, while negative density effects like competition will occur

250 more in low stress environments (i.e., the stress-gradient hypothesis, SGH: Bertness \& Callaway

251 1994). Because habitats being restored are often degraded areas with high physical stress,

252 positive density effects may emerge and be important for improving restoration success. 
254 transplants have found both negative and positive density dependence. The first study to

255 manipulate density (corals spaced 5-cm apart) and planting configuration of staghorn coral

256 (Acropora cervicornis) found increase density significantly reduced coral growth within the first

2573 months of transplantation, likely due to competition for space (Griffin et al. 2015) (Fig. 4). In

258 the Philippines, Shaish et al. (2010) found no difference in colony survivorship of transplanted

259 Montipora digitata in high density (spaced 10-cm apart) and low density (spaced 20-cm apart)

260 plots over 15 months. These studies suggest studies examining the effects of density on coral

261 transplants may have varied results depending on spacing between colonies. For endangered

262 Caribbean acroporid corals, recent experimental research shows a unimodal relationship may

263 exist, with positive density effects occurring at moderate levels $\left(3\right.$ corals $\left.\mathrm{m}^{-2}\right)$ but negative

264 density effects occurring at higher densities (Ladd et al. 2016). However, strong positive density

265 effects have been found under natural settings in A. cervicornis thickets at high density levels

266 due to a positive feedback loop between these branching corals and the fish that live within their

267 branches and provide nutrients through excrement (Huntington et al. 2017) (Fig. 4).

While most of these studies examine colony-specific metrics, such as growth and

269 survivorship of individual corals, the effects of density are likely affected by environmental

270 stressors and temporal scales. Although ecological theory (e.g., the SGH) suggests that positive

271 density dependency may emerge under high stress conditions in coral reefs, no studies to date

272 have examined how the impacts of density vary across a stress gradient. For instance, because of

273 the tendency of branching corals to fuse, higher density plots may enhance structural resistance

274 to wave energy such as intense storms (as suggested in Griffin et al. 2015), yet no study to date

275 has examined this type of positive density effect. Similarly, higher density plots may also 
276 enhance structural complexity that attracts more fish (e.g., promoting nutrient transfer) or

277 invertebrates (e.g., that promote corals through mutualisms or trophic facilitation) (Fig. 2).

278 Clearly, further research on the role of density in promoting coral restoration is needed,

279 specifically studies that focus on how density varies along realistic and commonly occurring

280 stress gradients, like wave stress, heat stress, turbidity, and coral predation.

282 Positive legacy effects

283 Legacy effects, which can be both negative and positive, occur when species interactions

284 have a lasting impact on an ecological community well past the time of the initial interaction.

285 One example is the effect of ditching on salt marshes in the 1930's, where the immediate

286 negative legacy effect of this human-ecosystem interaction included changes to plant

287 distributions, fish and insect abundance, and hydrological patterns that benefited some species

288 but suppressed others (Silliman, Grosholz, and Bertness 2009). Only recently, a positive legacy

289 effect was found that ditched marshes are more susceptible to runaway grazing by crabs and

290 subsequent community die-off because ditched marshes are dominated by plants that are

291 preferred by grazing crabs (Coverdale et al. 2013). A legacy effect evident in the context of

292 restoration includes oyster reefs, which have been decimated by disease and overharvesting over

293 the last century (Beck et al. 2011). Although the individuals that built remnant oyster reefs

294 decades ago are gone, their skeletons remain and are commonly used to facilitate oyster

295 recruitment (i.e., 'spat') (Schrack et al. 2012).

296 Although legacy effects on coral reefs have not been intensely studied, we consider here

297 one strong example that could be used in restoration. Like oyster reefs, coral skeletons remain

298 present on reefs for many years after the veneer of living coral tissue has disappeared. In the 
299 same way that oyster spat recruits to old oyster shell, new coral recruits or transplants may also

300 benefit from settling or growing on old skeleton. For instance, corals may be able to grow faster

301 by re-sheeting tissue over the skeleton rather than expending energy on producing new skeleton.

302 Indeed, a reef in Palau was found to recover quickly after a bleaching event because corals

303 regrew tissue over former skeletons rather than laying down new skeleton (Roff et al. 2014).

304 Growing on coral skeletons can also keep smaller, more susceptible coral transplants away from 305 competitors or predators. For instance, coral larvae are known to avoid reefs with high algal

306 cover, but will settle on structures above the substrate to avoid competitive algae (Dixson,

307 Abrego, and Hay 2014). Likewise, corallivores might prefer to feed at low elevations or avoid

308 high elevations to potentially avoid predation (E Shaver pers. comm.). The potential to use coral

309 skeletons in a restoration context has recently been realized, for instance using new techniques

310 (i.e., micro-fragging: Forsman et al. 2015) to restore reef-building boulder corals in Florida.

311 Much more research is required, however, to understand and maximize the benefits of coral

312 skeletons in coral restoration efforts and to identify other legacy effects that can be used to

313 increasing the efficiency of coral restoration efforts.

\section{Biodiversity and ecosystem function}

316 Biodiversity encompasses the species, genetic, functional, and ecological diversity of

317 living things. Decades of research have shown that for a great variety of marine and terrestrial

318 ecosystems, there is a positive relationship between biodiversity and ecosystem function,

319 (Tilman et al. 1997, Hooper and Vitousek 1997, Kinzig et al. 2002, Hooper et al. 2005, and

320 Srivastava and Vellend 2005). For example, Maester et al. (2012) found that diversity of plant

321 species in semi-arid ecosystems (e.g., drylands) enhanced carbon and nutrient cycling as well as 
322 overall ecosystem multifunctionality. In addition to higher ecosystem productivity and

323 functioning, studies have also shown that biodiversity increases ecosystem resilience to

324 disturbance. Proposed mechanisms behind the positive impacts of biodiversity on ecosystem

325 function and resilience include the asynchrony of species responses to environmental changes or

326 disturbances (e.g., the portfolio effect: Tilman 1999, Loreau 2010) and increased functional

327 redundancy, leading to higher resilience and the maintenance of ecological functioning if one or

328 a few species are lost (e.g., the insurance hypothesis: Yachi \& Loreau 1999).

329 The most commonly used techniques for coral restoration today (e.g., coral gardening

330 and outplanting: Lirman and Schopmeyer 2016) were designed to restore branching corals in

331 response to severe declines in the populations of two formerly dominant Caribbean acroporid

332 corals after disease and bleaching events (staghorn coral: A. cervicornis; elkhorn coral: $A$.

333 palmata; Gardner et al. 2003). Coral restoration projects across the globe also largely focus

334 efforts on a few species of branching corals (e.g., Acropora spp. and Pocillopora spp.), due to a

335 history of restoration methods that take advantage of their high growth rates and ease of

336 propagation through fragmentation (Johnson et al. 2011, Rinkevich 2014). However, coral reefs

337 in both regions have a diversity of coral species and many massive coral species can be

338 important reef-builders (e.g., Orbicella spp.). In addition, Caribbean branching corals can be

339 more susceptible to natural enemies such as predators and disease (Bruckner 2002, Baums et al.

340 2003), and due to ecological trade-offs with competitive dominance, tend to be less tolerant of

341 environmental stressors like warm temperatures and bleaching (Loya et al. 2001). Because

342 natural enemies and climate change continue to impede restoration efforts (NMFS 2015) and

343 because coral reefs naturally harbor a greater diversity of corals than just two species, 
344 reestablishing a range of coral biodiversity, including species and growth forms, may enhance

345 success and facilitate ecosystem resilience.

346 Several experiments manipulating coral species richness have found improved coral

347 growth and survivorship in mixed versus single species plots. For instance, Dizon \& Yap (2005)

348 found that colonies of Porites cylindrica had higher growth rates when transplanted in plots with

349 other species (Porities rus and Pavona frondifera) relative to conspecifics, however this

350 facilitation stopped when nutrient enrichment was introduced to plots. Diverse coral species

351 facilitated $A$. cervicornis growth and survivorship by reducing the number of coral predators

352 (Coralliophila abbreviata) that attacked plots of A. cervicornis (Johnston and Miller 2014).

353 Similarly, Cabaitan et al. (2015) found that transplants of the coral Pavona frondifera had higher

354 success when planted with the coral Porites cylindrica, but only in stressful environments with

355 high wave energy. In addition, P. cylindrica also appeared to reduced predation on $P$. frondifera

356 by starfish and snails (Cabaitan et al. 2015). Additionally, Montoya-Maya et al. 2016 found

357 successful coral recruitment in areas transplanted mixed coral species, though this study did not

358 manipulate diversity and all species used were acroporid or pocilloporid (e.g., branching) corals.

359 Importantly, restoring diverse functional traits (e.g, growth forms) in addition to species may

360 also increase the resilience of restored sites to climate-change impacts (e.g., bleaching events or

361 intense storms), as boulder corals may be more likely to withstand these stressors (Loya et al.

362 2001). Luckily, new techniques are being designed to improve the propagation of other coral

363 species (Lirman and Schopmeyer 2016). Future research should examine how coral diversity

364 effects transplant success (growth, mortality, recruitment) as well as long-term ecological

365 stability (resistance and recovery processes). These efforts may be especially important in the 
366 Caribbean, where it is thought that low diversity relative to the Indo-Pacific has reduced its

367 ability to recover after disturbance.

\section{Conclusion and recommendations}

Restoration is currently being elevated as a major conservation strategy to help combat

371 coral loss in the Caribbean and across the globe. For this to be realized, the efficacy of

372 restoration efforts must increase long-term coral transplant growth and survivorship while

373 reducing associated costs. It is important to note that like other marine and terrestrial ecosystems,

374 active transplantation efforts are likely to be successful only in sites where environmental or

375 local stressors have been successfully reduced (e.g., effective MPAs) or in areas where stress is

376 not an issue but recruitment limitation is impeding natural recovery (Orth et al. 2012). For new

377 techniques and designs to help increase the scale of coral restoration efforts, these restorative

378 efforts thus must also be tied to successful management strategies.

380 been suggested (Halpern et al. 2007, Gedan and Silliman 2009) and demonstrated (Silliman et al.

3812015 ) as one primary way scaling up restoration efforts can be accomplished in other aquatic

382 habitats. Coral reef managers have used positive interactions for decades to promote corals with

383 a well-known trophic facilitation by algae-eating herbivores, but have not yet identified other

384 positive species interactions specifically for use in coral restoration designs. In this paper, we

385 highlight several other general facilitative mechanisms that could be used by coral restoration 386 practitioners when designing future projects. Although this paper is focused on facilitations, the

387 relative effects of negative (e.g., competition and predation) and positive interactions (facilitation

388 and mutualism) are likely to vary depending on the species or organisms present and the 
389 environment conditions or characteristics of that site (He et al. 2013). Nonetheless, below we

390 recommend general facilitative mechanisms that deserve further testing and consideration in

391 restoration designs including:

392 1) Identifying specific trophic linkages or food webs that promote coral health and

393 transplanting corals in areas with where these food webs are robust and protected.

394 2) Identifying mutualisms between corals and other reef- or coral-associated organisms

395 that promote coral health and enhancing or protecting these mutualistic partners.

396 3) Locating sites for coral restoration close to healthy and well-functioning seagrass and

397 mangrove habitats and protecting these habitats from extractive or destructive uses.

398 4) Identifying species-specific density effects for corals of restoration interest to take

399 advantage of transplant densities that facilitate coral growth or survivorship.

400 5) Exploring the legacy of former reef-builders or occupiers, such as coral skeletons left behind, for use in coral transplantation.

402

6) Determining ways in which increased coral diversity facilitates the success of coral transplants as well as the long-term success of the restored coral reef community to environmental fluctuations and disturbances (e.g., resilience). 


\section{$412 \quad$ Literature Cited}

413 1. Allee WC. 1931. Animal aggregations: A study in general sociology. University of 414 Chicago Press., Chicago.

415 2. Angelini C, Griffin JN, van de Koppel J, Lamers LP, Smolders AJ, Derksen-Hooijberg 416 M, van der Heide T, Silliman BR. 2016. A keystone mutualism underpins resilience of a 417 coastal ecosystem to drought. Nature Communications 18:7.

418 3. Beck MW, Brumbaugh RD, Airoldi L, Carranza A, Coen LD, Crawford C, Defeo O, 419 Edgar GJ, Hancock B, Kay MC, Lenihan HS. 2011. Oyster reefs at risk and recommendations for conservation, restoration, and management. Bioscience 61:107-16.

4. Bergsma GS, Martinez CM. 2011. Mutualist-induced morphological changes enhance growth and survival of corals. Marine Biology 158:2267.

5. Bergsma GS. 2012. Epibiotic mutualists alter coral susceptibility and response to biotic disturbance through cascading trait-mediated indirect interactions. Coral Reefs 31:461-9.

6. Bertness M, Callaway RM. 1994. Positive interactions in communities. Trends in Ecology and Evolution 9:191-193.

7. Beschta RL, Ripple WJ. 2009. Large predators and trophic cascades in terrestrial ecosystems of the western United States. Biological Conservation 142:2401-14.

8. Biggs BC. 2013. Harnessing natural recovery processes to improve restoration outcomes: an experimental assessment of sponge-mediated coral reef restoration. PloS One 8:e64945.

9. Bruckner AW. 2002. Proceedings of the Caribbean Acropora Workshop: Potential application of the U.S. Endangered Species Act as a conservation strategy. NOAA Technical Memorandum NMFS-OPR-24, Silver Spring, MD. 
10. Bruno J, Bertness MD. 2001. Positive Interactions, Facilitations and Foundation Species. In: Marine Community Ecology. M. D. Bertness, S. D. Gaines and M. Hay (Editors). Sinauer Associates, Sunderland Massachusetts. theory. Trends in Ecology \& Evolution 18:119-25.

12. Burke L, Reytar K, Spalding M, Perry A. 2011. Reefs at Risk Revisited. Washington, D.C., World Resources Institute, The Nature Conservancy, WorldFish Center, International Coral Reef Action Network, UNEP World Conservation Monitoring Centre and Global Coral Reef Monitoring Network.

13. Burkepile DE, Hay ME. 2007. Predator release of the gastropod Cyphoma gibbosum increases predation on gorgonian corals. Oecologia 154:167-73.

14. Burkepile DE, Hay ME. 2008. Herbivore species richness and feeding complementarity affect community structure and function on a coral reef. Proceedings of the National Academy of Sciences 105:16201-6.

15. Burkepile DE, Allgeier JE, Shantz AA, Pritchard CE, Lemoine NP, Bhatti LH, Layman CA. 2013. Nutrient supply from fishes facilitates macroalgae and suppresses corals in a Caribbean coral reef ecosystem. Scientific Reports 20:1493.

16. Cabaitan PC, Yap HT, Gomez ED. 2015. Performance of single versus mixed coral species for transplantation to restore degraded reefs. Restoration Ecology 23:349-56.

17. Callan R, Nibbelink NP, Rooney TP, Wiedenhoeft JE, Wydeven AP. 2013. Recolonizing wolves trigger a trophic cascade in Wisconsin (USA). Journal of Ecology 101:837-45. 
456 18. Christianen MJ, van Belzen J, Herman PM, van Katwijk MM, Lamers LP, van Leent PJ,

457 Bouma TJ. 2013. Low-canopy seagrass beds still provide important coastal protection $458 \quad$ services. PloS One 8:e62413.

459 19. Coverdale T, Herrmann N, Altieri A, Bertness MD. 2013. Synergistic, delayed effects of 460 human impacts on ecosystems. Frontiers in Ecology and the Environment 11:69-74.

461 20. Daleo P, Fanjul E, Casariego AM, Silliman BR, Bertness MD, Iribarne O. 2007. Ecosystem engineers activate mycorrhizal mutualism in salt marshes. Ecology Letters $10: 902-8$

21. De Goeij JM, Van Oevelen D, Vermeij MJ, Osinga R, Middelburg JJ, de Goeij AF, Admiraal W. 2013. Surviving in a marine desert: the sponge loop retains resources within coral reefs. Science 342:108-10.

22. Dighton J, Mason PA. 1985. Mycorrhizal dynamics during forest tree development. In Developmental Biology of Higher Fungi. Pages 117-139. Cambridge University Press, Cambridge, UK.

23. Dixson DL, Abrego D, Hay ME. 2014. Chemically mediated behavior of recruiting corals and fishes: a tipping point that may limit reef recovery. Science 345:892-7.

472 24. Dizon RM, Yap HT. 2005. Coral responses in single-and mixed-species plots to nutrient 473 disturbance. Marine Ecology Progress Series 296:165-72.

474 25. Doak DF, Bigger D, Harding EK, Marvier MA, O'Malley RE, Thomson D. 1998 The statistical inevitability of stability-diversity relationships in community ecology. American Naturalist 151:264-276. 
477

478

479

480

481

482

483

484

485

486

487

488

489

490

491

492

493

494

495

496

497

498

26. Dorenbosch M, Grol MG, Christianen MJ, Nagelkerken I, Van Der Velde G. 2005. IndoPacific seagrass beds and mangroves contribute to fish density and diversity on adjacent coral reefs. Marine Ecology Progress Series 302:63-76.

27. Dorenbosch M, Verberk WC, Nagelkerken I, Van der Velde G. 2007. Influence of habitat configuration on connectivity between fish assemblages of Caribbean seagrass beds, mangroves and coral reefs. Marine Ecology Progress Series 334:103-16.

28. Dulvy NK, Freckleton RP, Polunin NV. 2004. Coral reef cascades and the indirect effects of predator removal by exploitation. Ecology Letters 7:410-6.

29. Estes JA, Palmisano JF. 1974. Sea otters: their role in structuring nearshore communities. Science 185:1058-60.

30. Forsman ZH, Page CA, Toonen RJ, Vaughan D. 2015. Growing coral larger and faster: micro-colony-fusion as a strategy for accelerating coral cover. PeerJ 3:e1313.

31. Gardner TA, Côté IM, Gill JA, Grant A, Watkinson AR. 2003. Long-term region-wide declines in Caribbean corals. Science 301:958-60.

32. Gascoigne JC, Lipcius RN. 2004. Allee effects driven by predation. Journal of Applied Ecology 41:801-10.

33. Gedan KB, Silliman BR. 2009. Using facilitation theory to enhance mangrove restoration. Ambio 38:109.

34. Gochfeld DJ, Aeby GS. 1997. Control of populations of the coral-feeding nudibranch Phestilla sibogae by fish and crustacean predators. Marine Biology 130:63-9.

35. González-Teuber M, Kaltenpoth M, Boland W. 2014. Mutualistic ants as an indirect defense against leaf pathogens. New Phytologist 202:640-50. 
36. Goreau TF, Goreau NI. 1959. The physiology of skeleton formation in corals. II. Calcium

500 deposition by hermatypic corals under various conditions in the reef. The Biological Bulletin (2):239-50.

37. Glynn PW. 1976. Some physical and biological determinants of coral community structure in the eastern Pacific. Ecological Monographs 46:431-56.

38. Griffin JN, Schrack EC, Lewis KA, Baums IB, Soomdat N, Silliman BR. 2015. Densitydependent effects on initial growth of a branching coral under restoration. Restoration Ecology. 23:197-200.

39. Halpern BS, Silliman BR, Olden JD, Bruno JP, Bertness MD. 2007. Incorporating positive interactions in aquatic restoration and conservation. Frontiers in Ecology and the Environment 5:153-60.

40. Harms KE, Wright SJ, Calderón O, Hernández A, Herre EA. 2000. Pervasive densitydependent recruitment enhances seedling diversity in a tropical forest. Nature 404:493-5. results typical? Ecology 65:446-54.

42. He Q, Bertness MD, Altieri AH. 2013. Global shifts towards positive species interactions with increasing environmental stress. Ecology Letters 16:695-706. Reefs 18:273-9.

44. Hooper DU, Vitousek PM. 1997. The effects of plant composition and diversity on ecosystem processes. Science 277:1302-5. 
520 45. Hooper DU, Chapin FS, Ewel JJ, Hector A, Inchausti P, Lavorel S, Lawton JH, Lodge

521 DM, Loreau M, Naeem S, Schmid B. 2005. Effects of biodiversity on ecosystem

522 functioning: a consensus of current knowledge. Ecological Monographs 75:3-5.

523 46. Huntington BE, Miller MW, Pausch R, Richter L. 2017. Facilitation in Caribbean coral

524 reefs: high densities of staghorn coral foster greater coral condition and reef fish

525 composition. Oecologia $1-1$.

526 47. Jackson J, Donovan M, Cramer K, Lam V. 2014. Status and trends of Caribbean coral

527 reefs: 1970-2012. Global Coral Reef Monitoring Network.

528 48. Johnson ME, Lustic C, Bartels E, Baums IB, Gilliam DS, Larson EA, Lirman D, Miller

529 MW, Nedimyer K, Schopmeyer S. 2011. Caribbean Acropora restoration guide: best

530 practices for propagation and population enhancement. The Nature Conservancy,

$531 \quad$ Arlington, VA.

532 49. Johnston L, Miller MW. 2014. Negative indirect effects of neighbors on imperiled

533 scleractinian corals. Coral Reefs 33:1047-56.

534 50. Kinzig AP, Pacala SW, Tilman D. 2002. The functional consequences of biodiversity.

535 Empirical progress and theoretical expectations. Princeton University Press.

536 51. Kuffner IB, Toth LT. 2016. A geological perspective on the degradation and conservation

537 of western Atlantic coral reefs. Conservation Biology 30:706-15.

538 52. Ladd MC, Shantz AA, Nedimeyer K, Burkepile DE. 2016. Density dependence drives

539 habitat production and survivorship of Acropora cervicornis used for restoration on a

$540 \quad$ Caribbean coral reef. Frontiers in Marine Science 3:261. 
541 53. Lamb JB, van de Water JA, Bourne DG, Altier C, Hein MY, Fiorenza EA, Abu N, Jompa

542 J, Harvell CD. 2017. Seagrass ecosystems reduce exposure to bacterial pathogens of

543 humans, fishes, and invertebrates. Science 355:731-3.

544 54. Levitan DR. 1991. Influence of body size and population density on fertilization success

545 and reproductive output in a free-spawning invertebrate. The Biological Bulletin 181:261-

$546 \quad 8$.

547 55. Lirman D, Schopmeyer S. 2016. Ecological solutions to reef degradation: optimizing $548 \quad$ coral reef restoration in the Caribbean and Western Atlantic. PeerJ 4:e2597.

549 56. Loreau M. 2010. Linking biodiversity and ecosystems: towards a unifying ecological 550 theory. Philosophical Transactions of the Royal Society of London B 365:49-60.

551 57. Loya Y, Sakai K, Yamazato K, Nakano Y, Sambali H, van Woesik R. 2001. Coral 552 bleaching: the winners and the losers. Ecology Letters 4:122-131

553 58. Maestre FT, Quero JL, Gotelli NJ, Escudero A, Ochoa V, Delgado-Baquerizo M, García554 Gómez M, Bowker MA, Soliveres S, Escolar C, García-Palacios P. 2012. Plant species 555 richness and ecosystem multifunctionality in global drylands. Science 335:214-8.

556 59. Maya PH, Smit KP, Burt AJ, Frias-Torres S. 2016. Large-scale coral reef restoration 557 could assist natural recovery in Seychelles, Indian Ocean. Nature Conservation 16:1. 558 60. McClanahan TR. Dynamics of Drupella cornus populations on Kenyan coral reefs. Proceedings of the $8^{\text {th }}$ International Coral Reef Symposium 1:633-638.

560 61. Meyer DL, Townsend EC, Thayer GW. 1997. Stabilization and erosion control value of oyster cultch for intertidal marsh. Restoration Ecology 5:93-99 
62. Mumby PJ, Edwards AJ, Arias-González JE, Lindeman KC, Blackwell PG, Gall A, Gorczynska MI, Harborne AR, Pescod CL, Renken H, Wabnitz CC. 2004. Mangroves enhance the biomass of coral reef fish communities in the Caribbean. Nature 427:533-6. KE, Mendes JM, Broad K, Sanchirico JN, Buch K. 2006. Fishing, trophic cascades, and the process of grazing on coral reefs. Science 31:98-101.

64. Mumby PJ. 2009. Herbivory versus corallivory: are parrotfish good or bad for Caribbean coral reefs? Coral Reefs 28:683-90. Moriniere EC, Nienhuis PH. 2002. How important are mangroves and seagrass beds for coral-reef fish? The nursery hypothesis tested on an island scale. Marine Ecology Progress Series 244:299-305.

66. National Marine Fisheries Service (NMFS). 2015. Recovery plan for elkhorn (Acropora palmata) and staghorn (A. cervicornis) corals. Prepared by the Acropora Recovery Team for the National Marine Fisheries Service, Silver Spring, Maryland.

67. Ogden JC, Lobel PS. 1978. The role of herbivorous fishes and urchins in coral reef communities. Environmental Biology of Fishes 3:49-63. eelgrass recovery in a coastal bay system. Marine Ecology Progress Series 448:177-95. African savanna. Science 319:192-5. 
70. Pratchett M, Vytopil E, Parks P. 2000. Coral crabs influence the feeding patterns of crown-of-thorns starfish. Coral Reefs 19:36.

71. Pratchett MS. 2001. Influence of coral symbionts on feeding preferences of crown-ofthorns starfish Acanthaster planci in the western Pacific. Marine Ecology Progress Series 214:111-9.

72. Rinkevich B. 2014. Rebuilding coral reefs: does active reef restoration lead to sustainable reefs? Current Opinion in Environmental Sustainability 7:28-36.

73. Roff G, Bejarano S, Bozec Y-M, Nugues M, Steneck RS, Mumby PJ. 2014. Porites and the Phoenix effect: unprecedented recovery after a mass coral bleaching event at Rangiroa Atoll, French Polynesia. Marine Biology 161:1385-1393.

74. Rotjan RD, Lewis SM. 2008. Impact of coral predators on tropical reefs. Marine Ecology Progress Series 367:73-91.

75. Ruppert JL, Travers MJ, Smith LL, Fortin MJ, Meekan MG. 2013. Caught in the middle: combined impacts of shark removal and coral loss on the fish communities of coral reefs. PloS One 8:e74648.

76. Sandin SA, Smith JE, DeMartini EE, Dinsdale EA, Donner SD, Friedlander AM, Konotchick T, Malay M, Maragos JE, Obura D, Pantos O. 2008. Baselines and degradation of coral reefs in the northern Line Islands. PloS One 3:e1548. territoriality on recovering populations of the threatened staghorn coral, Acropora cervicornis. PloS One 10:e0141302.

78. Schrack E, Beck M, Brumbaugh R, Crisley K, Hancock B. 2012. Restoration works: Highlights from a decade of partnership between The Nature Conservancy and the 

Conservancy, Arlington, VA.

79. Shaish L, Levy G, Katzir G, Rinkevich B. 2010. Employing a highly fragmented, weedy coral species in reef restoration. Ecological Engineering 36:1424-32. shape coral reef benthic communities. Ecological Applications 25:2142-52. perspective. University of California Press. van de Koppel J. Facilitation shifts paradigms and can amplify coastal restoration efforts. 2015. Proceedings of the National Academy of Sciences 112:14295-300. cascades in African savanna: Serengeti as a case study. In Trophic Cascades: Predators, Prey and the Changing Dynamics of Nature. 20:255-74. to conservation? Annual Review of Ecology, Evolution, and Systematics 36:267-94. effects of vermetid snails on a branching coral. Coral Reefs 29:1019-22. Ecology 68:844-56.

87. Storlazzi CD, Elias E, Field ME, Presto MK. 2011. Numerical modeling of the impact of sea-level rise on fringing coral reef hydrodynamics and sediment transport. Coral Reefs 30:83-96. 
630 88. Tilman D, Knops J, Wedin D, Reich P, Ritchie M, Siemann E. 1997. The influence of 631 functional diversity and composition on ecosystem processes. Science 277:1300-2.

632 89. Tilman D. 1999. The ecological consequences of changes in biodiversity: a search for 633 general principles. Ecology 80:1455-74.

634 90. Valentine JF, Heck KL. 2005. Perspective review of the impacts of overfishing on coral 635 reef food web linkages. Coral Reefs 24:209-13.

636 91. van de Koppel J, van der Heide T, Altieri AH, Eriksson BK, Bouma TJ, Olff H, Silliman

637 BR. 2015. Long-distance interactions regulate the structure and resilience of coastal 638 ecosystems. Annual review of Marine Science 7:139-158.

639 92. van der Heide T, Govers LL, de Fouw J, Olff H, van der Geest M, van Katwijk MM,

640 Piersma T, van de Koppel J, Silliman BR, Smolders AJ, van Gils JA. 2012. A three-stage $641 \quad$ symbiosis forms the foundation of seagrass ecosystems. Science 336:1432-4.

642 93. Williams DE, Miller MW, Bright AJ, Cameron CM. 2014. Removal of corallivorous 643 snails as a proactive tool for the conservation of acroporid corals. PeerJ 2:e680.

644 94. Wilkinson C. 2004. Status of Coral Reefs of the World: 2004. Volume 1. Australian 645 Institute of Marine Science. Townsville, Queensland, Australia.

95. Yachi S, Loreau M. 1999 Biodiversity and ecosystem productivity in a fluctuating environment: the insurance hypothesis. Proceedings of the National Academy of Science of the United States of America 96:1463-1468.

650

96. Young CN, Schopmeyer SA, Lirman D. 2012. A review of reef restoration and coral propagation using the threatened genus Acropora in the Caribbean and Western Atlantic. Bulletin of Marine Science 88:1075-1098. 


\section{$653 \quad$ Figures}

654

655 Figure 1. Number of coral restoration studies from a Web of Science search for TOPIC: (“Coral

656 Restoration”), OR TOPIC: (“Coral Propagation”) OR TOPIC: (“Coral Gardening”) OR TOPIC:

657 (“Coral Nurseries”) from 1980-2016 that examine negative interactions (i.e., competition,

658 predation) and positive interactions (i.e., facilitation, mutualism, cooperation) or neither.

659

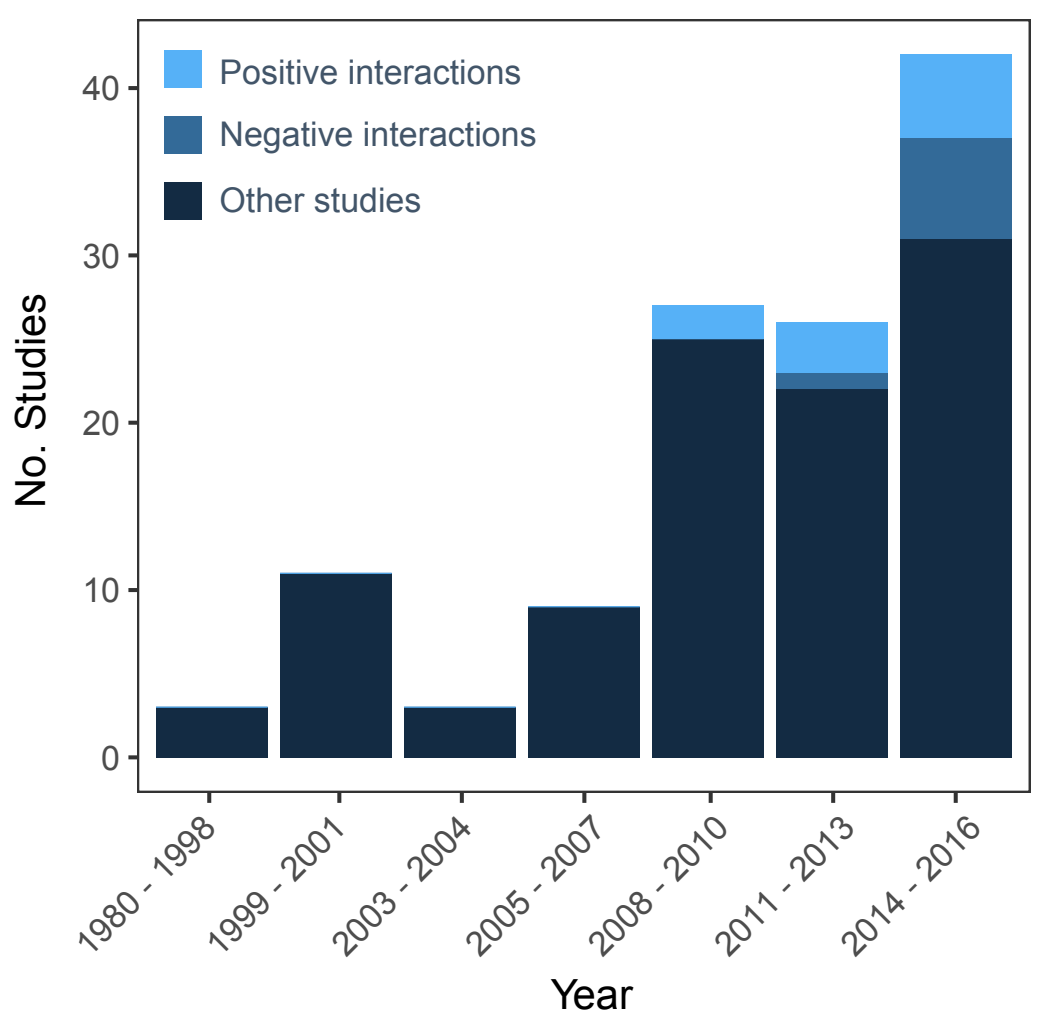


666 Figure 2. Trophic interactions and feedback loops between corals and reef inhabitants. A) Reefs

667 with high coral cover and diversity support higher levels of herbivores (e.g., fish and urchins)

668 that reduce macroalgae and meso-predators. Meso-predators reduce populations of corallivores,

669 and herbivores reduce macroalgae, which both promote increased coral cover. Additionally,

670 herbivores and meso-predators produce more biotic-derived nutrients that enhance coral growth.

671 These effects all facilitate healthy coral communities. B) Reefs with low coral cover and

672 diversity support fewer herbivores and meso-predators, leading to increased macroalgae and

673 corallivores but less biotic nutrients. These effects further reduce coral cover. Photo credits: (left)

674 Kemit Amon-Lewis, The Nature Conservancy; (right) Elizabeth Shaver, Duke University.

A.

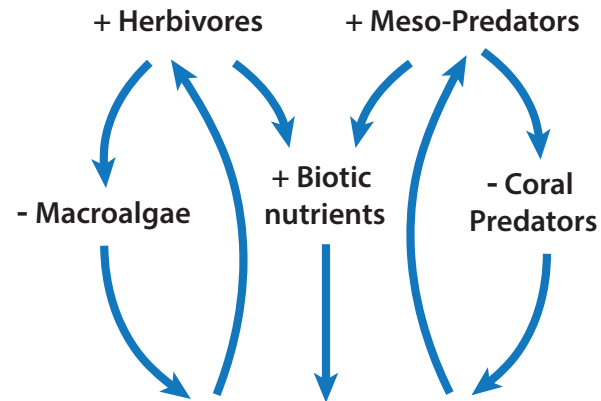

High Coral Cover \& Diversity Reef

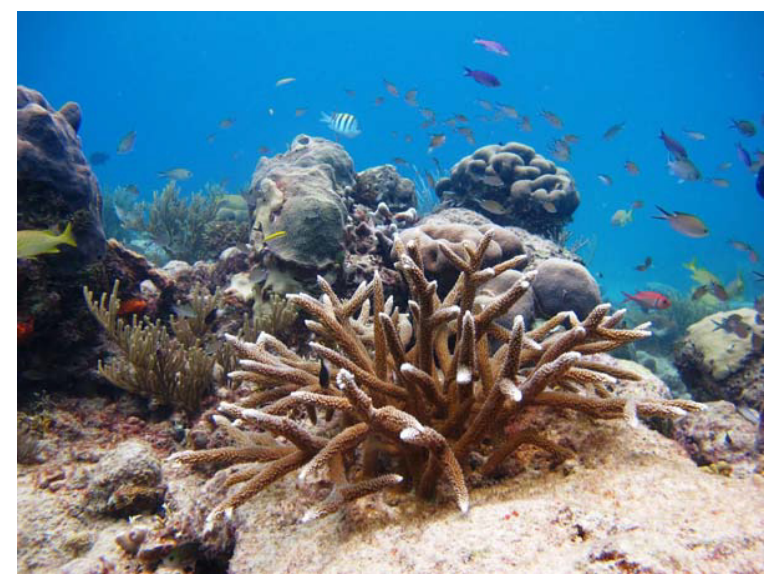

B.

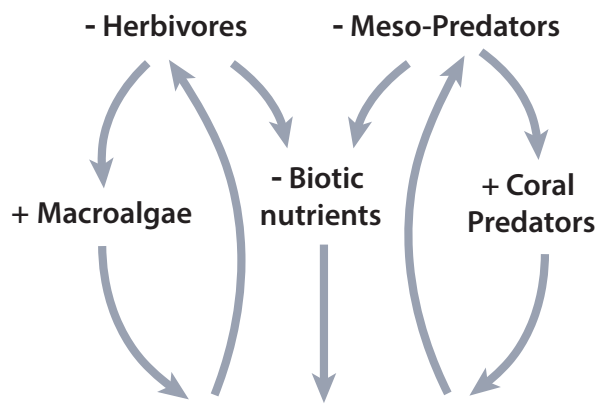

Low Coral Cover \& Diversity Reef

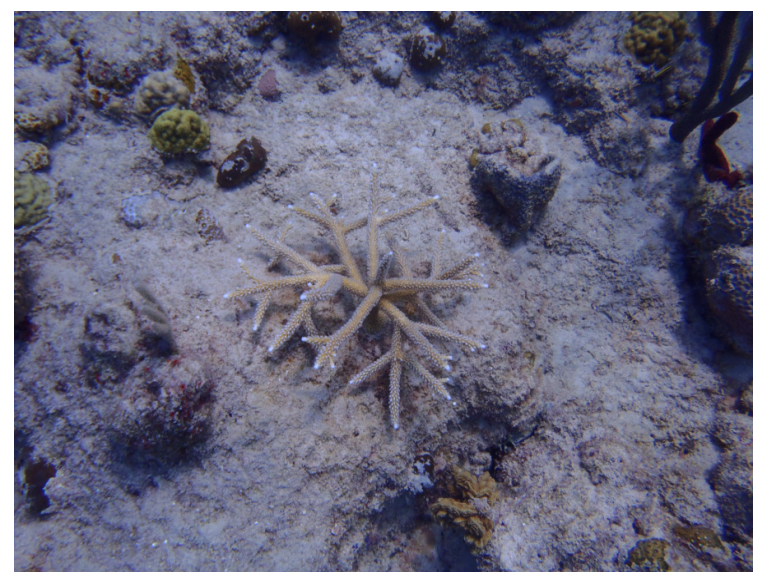


677 Figure 3. Potential effects of long-distance interactions on coral transplants a) with and b)

678 without adjacent, healthy mangrove and seagrass habitats. Brown lines indicate the movement of

679 coastal or watershed-based run-off (which carry sediments, excess nutrients, and pollutants) from

680 land that gets reduced by mangrove forests and seagrass beds before going on to coral

681 reefs. Purple lines depict microbial cycling by seagrasses that reduces pathogens and coral

682 disease. Thick lines indicate large effects or movements of particles, whereas thin lines indicate a

683 small effects or movements of particles. In Panel A, there is a abundance of herbivores, including

684 greater diversity of parrotfish, due to nearby nursery habitat and food provisioning of mangroves

685 and seagrasses, which leads to reduced macroalgae abundance on reefs. In Panel B, there are

686 fewer herbivores, more algae, disease, and run-off on reefs, leading to reduced success of coral

687 transplants. Image credit (vector graphics): Catherine Collier, Jane Hawkey, Tracey Saxby, and

688 Joanna Woerner, Integration and Application Network, University of Maryland Center for

689 Environmental Science (ian.umces.edu/imagelibrary/) 
A. Reduced runoff (sediment, fertilizers, pollutants)

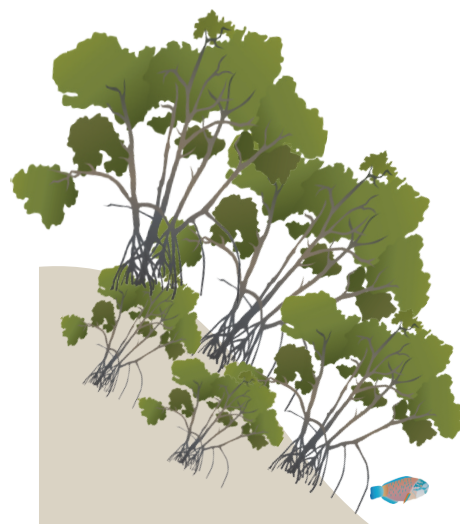

ncreased herbivores

\& excrement

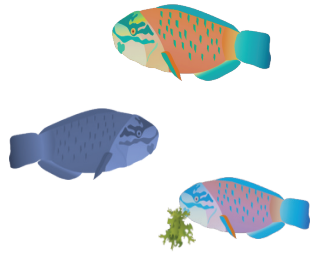

Reduced 繁/ pathogens

Mangroves

Seagrasses

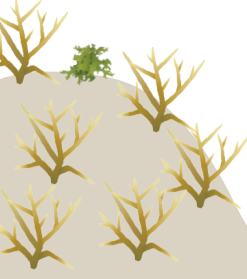

Coral Reefs

B.

Increased runoff (sediment, nutrients, pollutants)

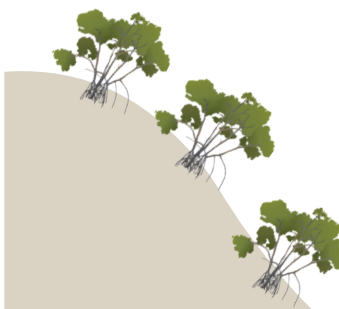

Reduced herbivores

\& excrement

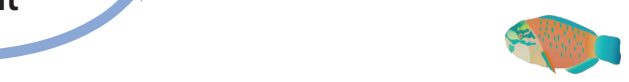

691

692

693

694

695 
696 Figure 4. Manipulations of coral transplant density and spacing during restoration, including

697 experimental research by Griffin et al. (2015) in which Caribbean staghorn corals (Acropora

698 cervicornis) were spaced close together (A) and far apart (B) (photograph was taken further

699 away from corals in photo B). Photo credits: John Griffin, Swansea University, United Kingdom.

700 Within a restoration program, restored corals are often planted in varying arrangements, for

701 instance spaced apart in lower densities (C) or closer together to mimic a natural high-density

702 acroporid thicket (D). Photo credits: Kemit Amon-Lewis, The Nature Conservancy. All pictures

703 were taken in the U.S. Virgin Islands.

704
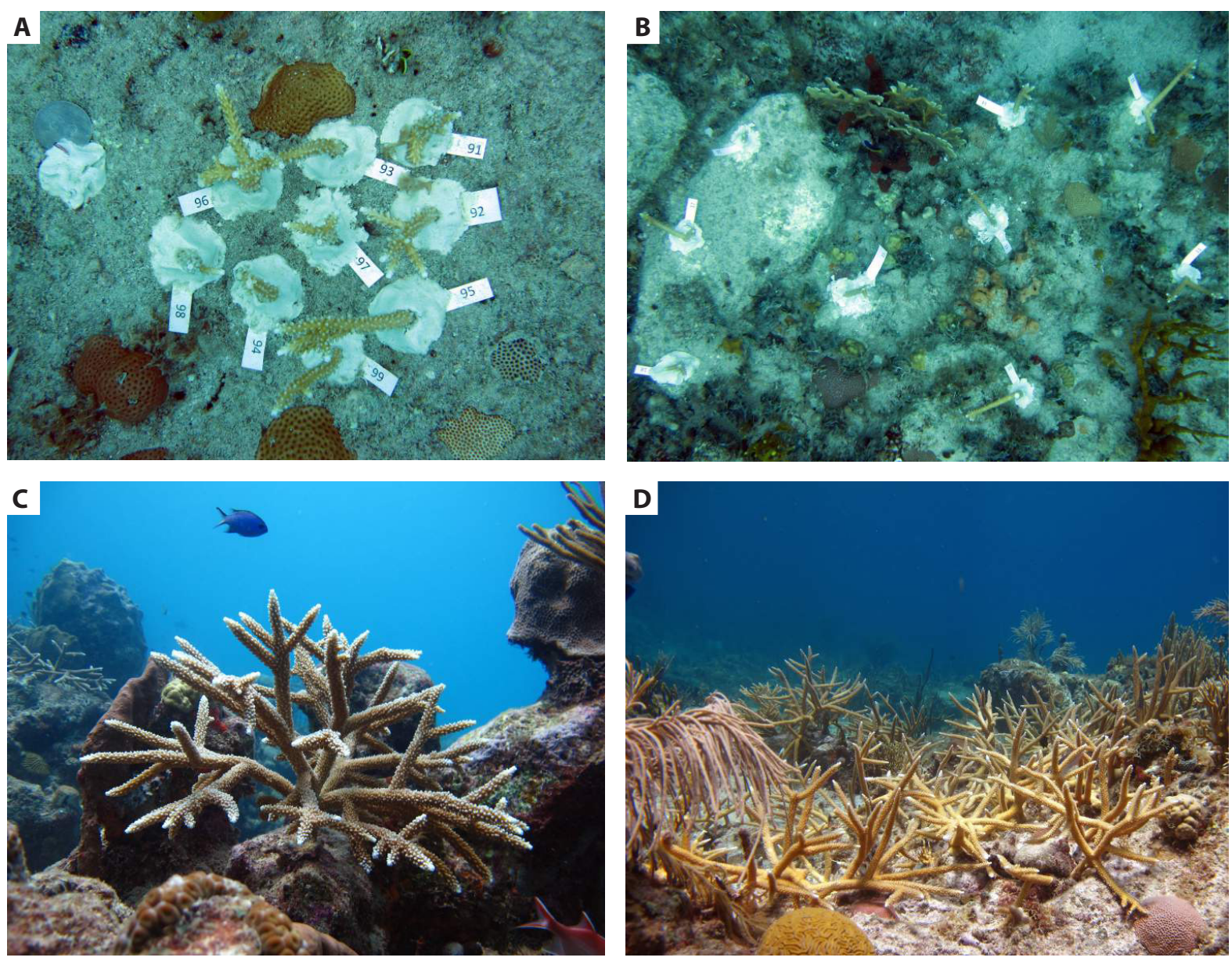